\title{
1. Explaining America's spendthrift healthcare system: the enduring effects of public regulation on private competition
}

\section{William M. Sage}

The United States is often described as the only developed nation without a public commitment to universal health care. Instead, its healthcare system is widely considered a product of bio-scientific free enterprise technologically sophisticated, extremely expensive, but inaccessible to the poor. Moreover, what initially appeared to be a dramatic change in U.S. health policy - the enactment of 'Obamacare' in 2010 - seems to have foundered on the shoals of partisan politics and nativist resistance to redistributing resources for the benefit of an increasingly diverse population.

This chapter offers a contrasting account, refuting the conventional narrative of U.S. health policy as private, competitive, and entrepreneurial. Beginning over 20 years ago, the poor performance of the American healthcare system has been slowly revealed. For nearly as long, steps that might improve that performance have been identified. But little has changed. Why? The answer, in large part, lies in an accumulation of laws, regulations, self-regulatory practices, and financial subsidies which locks U.S. healthcare into inefficient, unfair patterns and practices. While most of these provisions were well-intentioned when put into place, this 'deep legal architecture' now serves mainly to prevent meaningful competition in medical markets and to distort or limit collective investment in the nation's health. 


\section{THE AMBITIONS OF 'OBAMACARE'}

The Patient Protection and Affordable Care Act of 2010, ${ }^{1}$ usually abbreviated as 'ACA' but popularly known as 'Obamacare,' was a very ambitious law. Unlike any previous effort to reform the U.S. healthcare system, the ACA set out to make simultaneous improvements in three related but distinct health policy domains: health insurance; healthcare services; and health.

Title I of the law, called 'Quality, Affordable Care for All Americans,' and Title II of the law, 'Role of Public Programs,' addressed the two major problems with American health insurance. The first problem was lack of insurability: that individuals with serious illnesses or disabilities, or estimated to be at high risk of developing them, were denied coverage by private insurance companies. The second problem was lack of affordability: private health insurance is so expensive that even young, healthy people cannot pay for it from an average income. As a result, nearly all Americans with private health insurance obtained it as a fringe benefit of employment; hardly any purchased it directly.

Insurability and affordability of health insurance are not difficult problems for a wealthy nation to solve, at least in the short term. The ACA did so by building on forms of health insurance that already exist in the U.S., rather than by creating a new, universal insurance scheme. Making nearly everyone insurable required two legal changes. First, the ACA put in place non-discrimination rules for private insurers to ensure that health insurance policies would be issued and renewed at level premiums (i.e., community rating), without regard to health status and varying only slightly by age (in the U.S., persons over age 65 are already covered by the national Medicare program). ${ }^{2}$ Second, the ACA imposed a requirement on individuals to possess health insurance coverage as long as it was reasonably available - usually referred to as the 'individual mandate' - or pay an income tax penalty if they chose not to. ${ }^{3}$ Combined with a standard set of 'essential health benefits' and state-based 'marketplaces' to broker

1 Patient Protection and Affordable Care Act, Pub. L. No. 111-148, 124 Stat. 119 (2010) (codified as amended in scattered sections of the U.S.C.).

2 Patient Protection and Affordable Care Act, Pub. L. No. 111-148, tits. I-II, 124 Stat. 119, 130-353 (2010) (codified as amended in scattered sections of 26, 29, 30, and 42 U.S.C.).

Nat'l Fed'n of Indep. Bus. v. Sebelius, 567 U.S. 519 (2012) (upholding penalty payable on federal tax return for failure to have health insurance). In late 2017, Congress zeroed out the tax penalty in section 11081 of the Tax Cuts \& Jobs Act of 2017, as a practical matter eliminating the mandate. Pub. L. No. 115-97, 131 Stat. 2092 (Dec. 22, 2017) (codified at 26 U.S.C. 5000A). 
insurance purchases, these measures enabled individuals with healthcare needs to purchase coverage while reducing the threat of adverse selection that can jeopardize private insurance markets that are not permitted to set prices based on risk.

The immediate solution to unaffordability is money, and the ACA found new ways to provide it. ${ }^{4}$ The law offers income tax credits for persons earning between 100 and 400 per cent of the federal poverty level (FPL) who purchase coverage; for a family of four earning USD 35000 annually (150 per cent of FPL), 90 per cent of the premium is subsidized by the federal government. In addition, persons earning up to 250 per cent of FPL enjoy greatly reduced deductibles and co-payments, with the federal government paying the difference to private insurers. ${ }^{5}$ This degree of public funding had the additional benefit of countering adverse selection; healthy working class families were likely to purchase coverage at the subsidized price even if the nominal premium was more expensive than previously because of community rating. At the same, the ACA greatly expanded the Medicaid program to provide public insurance to all persons earning less than 138 per cent of FPL on a nationally uniform basis, replacing the highly variable and typically less generous Medicaid coverage previously made available by each state. Substantially as a result of these measures, the number of uninsured Americans dropped from 44 million in 2013 to 28 million in $2016 .^{6}$

The ACA did not stop there, however. Title III, 'Improving the Quality and Efficiency of Healthcare,' is not about health insurance but about the delivery of healthcare goods and services: hospitals, physicians, prescription drugs, diagnostics, and the like. ${ }^{7}$ Title IV, 'Prevention of Chronic Disease and Improving Public Health,' is about underlying health, which is only moderately influenced by medical care. ${ }^{8}$ These aspects of the law

4 Patient Protection and Affordable Care Act, sections 1401-1402.

5 The Trump administration ceased repaying insurers for uncollected costsharing obligations in late 2017. Juliet Eilperin, Amy Goldstein and Carolyn Y. Johnson, White House's Decision to End Cost-Sharing Subsidies Triggers Strong Opposition, Wash. Post, Oct. 13, 2017.

6 Henry J. Kaiser Foundation, Key Facts About the Uninsured Population, Sept. 19, 2017 (available at https://www.kff.org/uninsured/fact-sheet/key-factsabout-the-uninsured-population/, last accessed 18 January 2019).

7 Patient Protection and Affordable Care Act, Pub. L. No. 111-148, tit. III, 124 Stat. 119, 354-537 (2010) (codified as amended in scattered sections of 21, 29, and 42 U.S.C.).

8 Ibid. See generally Rachel Rebouche and Scott Burris, 'The Social Determinants of Health', in Oxford Handbook of U.S. Healthcare Law 1097 (I. Glenn Cohen et al. eds, 2016). 
recognize two harsh realities of social policy in the U.S.: its healthcare system is extraordinarily expensive, and the health of its population is not particularly good. ${ }^{9}$ In 2017 , U.S. per capita healthcare spending exceeded USD 10000 (and constituted 17.2 per cent of GDP), 25 per cent more in absolute numbers than the second most expensive nation (Switzerland, at 12.2 per cent of GDP) and more than double most developed countries with universal health coverage. ${ }^{10}$ In 1985 , the U.S. federal government's direct and indirect financial commitment to healthcare programs was 2.9 per cent of US GDP; by 2010, that number had grown to 7.6 per cent of US GDP. ${ }^{11}$ At the same time, U.S. life expectancy at birth dropped slightly in 2017 to 78.6 years, 1.5 years lower than the average among Organisation for Economic Co-operation and Development (OECD) countries. ${ }^{12}$ Infant mortality in the U.S. is the highest in the OECD and is improving more slowly than elsewhere; moreover, African-American families suffer infant mortality more than double that among non-Hispanic white families. ${ }^{13}$

The specific measures included in the ACA to improve healthcare and health are not as well-defined as those intended to expand insurance coverage, and confidence even among experts in their likelihood of success is not as great. Many are pilot programmes and demonstration projects rather than across-the-board, mandatory changes. Reforms to healthcare delivery include alternatives to fee-for-service payment of physicians and hospitals, new care models such as accountable care organizations and patient-centred medical homes, funding and oversight bodies

9 See, e.g., Steven H. Woolf and Laudan Y. Aron, The US Health Disadvantage Relative to Other High-Income Countries, 309 JAMA 771, 772 (2013) (comparing Americans' health to that of other countries of similar economic status).

10 OECD, Spending on Health: Latest Trends, June 2018 (available at http:// www.oecd.org/health/health-systems/Health-Spending-Latest-Trends-Brief.pdf).

11 Compilation of Congressional Budget Office data, available at https://www. usgovernmentspending.com/recent_spending, last accessed 18 January 2019.

12 OECD data available at https://data.oecd.org/healthstat/life-expectancy-atbirth.htm, last accessed 18 January 2019. International comparisons of healthcare system performance generally place the U.S. at or near the bottom. See Eric C. Schneider et al., 'Mirror, Mirror 2017: International Comparison Reflects Flaws and Opportunities for Better U.S. Health Care' (Commonwealth Fund 2017), http://www.commonwealthfund.org/ /media/files/publications/fund-report/2017/ jul/schneider_mirror_mirror_2017.pdf, last accessed 18 January 2019.

13 The rate for non-Hispanic African-Americans of 11.3 per 1000 live births is comparable to the infant mortality rate in Mexico, a country that spends roughly 10 per cent of what the United States spends on healthcare. Compare https://www.kff.org/other/state-indicator/infant-mortality-rate-by-race-ethnicity/ ?currentTimeframe $=0 \&$ sortModel $=\% 7 \mathrm{~B} \% 22$ colId $\% 22: \% 22$ Location $\% 22, \% 22$ sor $\mathrm{t} \% 22: \% 22 \mathrm{asc} \% 22 \% 7 \mathrm{D}$ to $\mathrm{https} / / /$ data.oecd.org/healthstat/infant-mortality-rates. htm\#indicator-chart, both last accessed 18 January 2019. 
such as the Patient-Centered Outcomes Research Institute (PCORI) and the Medicare Innovation Center, increased transparency to consumers regarding quality and price, a more flexible and diverse healthcare workforce, and a renewed commitment to health information technology. The health-related provisions of the ACA mainly involve greater funding for community health planning and improvement, associated workforce investments, and a few smaller changes such as more detailed nutritional information on restaurant menus.

In hindsight, following the 2016 U.S. presidential election, the ACA's extraordinary ambition may have overreached both its financial feasibility and its political support. Misinformation and partisanship aside, however, its more sweeping approach to national reform reflected a major shift in expert understanding of the U.S. healthcare system over the past 20 years. Somewhat surprisingly, the dramatic implications of this new knowledge are not explicitly acknowledged in public policy debates.

\section{RATIONING OR IMPROVEMENT: FROM TRAGIC CHOICE TO TRIPLE AIM}

Conventional wisdom in the 1980s, after the inflationary effects on healthcare spending of expanding insurance coverage through Medicare and Medicaid had become apparent, was that advances in medical technology would continually and inexorably push costs even higher. After all, improvements in medical knowledge and the technical capacity to treat illness had driven spending persistently upwards over the preceding century, and it was universally expected that the scientific progress so evident in nearly all human endeavours from the 1960s onward would drive medicine forward as well.

Therefore, health policy was invariably taught as a 'three-legged stool,' with the legs representing access to medical care, quality of care, and cost. Inherent in the 'stool' metaphor was the idea that the legs must be of roughly equal length for the system to function. Scholars and experts sometimes added 'innovation' as a fourth consideration to capture the dynamism of policy choices over time, but not to vary the basic image of balance or equipoise.

At the time, the U.S. healthcare system was widely praised for its scientific sophistication, with American political and medical leaders routinely describing it as 'the best in the world.' However, the U.S. lacked a universal health insurance entitlement, leading policy experts to conclude that (in Lawrence Jacobs' words), America prioritized supply - of new treatments, facilities, and practitioners - over access to those resources on a broad and 
equitable basis. ${ }^{14}$ As costs rose, the uncomfortable implication of using the balance of cost, access, and quality as one's analytical frame was that any effort to preserve or expand access without spending more would necessarily reduce quality - almost certainly by denying individuals expensive but potentially life-saving treatment. In other words, the rationing of medical care.

Although Victor Fuchs, Guido Calabresi and Philip Bobbitt, and others reached similar conclusions, ${ }^{15}$ William Kissick captured the challenge perfectly in a quote from his 1994 book, Medicine's Dilemmas: Infinite Needs Versus Finite Resources: 'No society in the world has ever been - or will ever be - able to afford providing all the health services its population is capable of utilizing. ${ }^{16}$ That same year, the newly elected Clinton administration sought to enact a universal health insurance entitlement based on principles of 'managed competition.' ${ }^{17}$ Although President Clinton, like all other American leaders before or after, ultimately refused to consider explicit rationing as part of U.S. health reform, many leading bioethicists who came to Washington, D.C. to advise on new legislation saw their role as helping him craft an ethical approach to resource allocation. ${ }^{18}$

One can argue that Kissick's analysis was outdated by the time he published it. Although breakthroughs in science and technology have accelerated since the 1980 s, their centrality to U.S. health policy has diminished in many expert views. Technology as a driver of health spending remains a critical consideration in a few domains, such as biopharmaceuticals, and generates important tensions between futurists and sceptics in a few others, such as 'precision' or 'personalized' medicine powered by genetic sequencing and cellular targeting. At the macro level, however, a new three-part framework has arguably superseded cost-access-quality in health policy analysis.

14 Laurence R. Jacobs, 'Politics of America's Supply State: Health Reform and Technology', 14 Health Aff. 143 (1995).

15 Guido Calabresi and Philip Bobbitt, Tragic Choices (New York: W.W. Norton, 1978); Victor R. Fuchs, Who Shall Live?: Health, Economics, and Social Choice (Singapore: World Scientific, 1975).

16 William Kissick, Medicine's Dilemmas: Infinite Needs Versus Finite Resources (New Haven CT: Yale University Press, 1994) 48.

17 Alain Enthoven and Richard Kronick, 'A Consumer-Choice Health Plan for the 1990s', 320 N. Engl. J. Med. 29 (1989); Paul Starr and Walter A. Zelman, 'A Bridge to Compromise: Competition Under a Budget', 12 Health Aff. 7 (Supp. 1993).

18 See, e.g., Norman Daniels and James E. Sabin, Setting Limits Fairly: Can We Learn to Share Medical Resources? (New York: Oxford Univ. Press, 2002). 
It is called the Triple Aim. ${ }^{19}$ Devised and refined by the Institute for Healthcare Improvement in Boston, and its longtime guru Don Berwick, the Triple Aim consists of improving the patient experience of care (including quality and satisfaction), improving the health of populations, and reducing the per capita cost of healthcare. Two novel aspects of the Triple Aim are immediately evident: examining care from the patient's perspective and becoming accountable for populations as well as individuals. But a third is far more important: whereas cost, access, and quality exist in perpetual tension with one another, the three parts of the Triple Aim are simultaneously achievable.

How can this be? The answer lies in the realization among both political theorists and health services researchers that the U.S. healthcare system is massively wasteful. Much medical practice is habitual rather than scientific. Where scientifically optimal care exists, even affluent, educated, insured patients often fail to receive it. Poorer, less educated patients and members of racial and ethnic minorities fare even worse, even if their care is publicly subsidized. Many new technologies layer themselves atop these flawed processes of care, adding expense but not yielding better results.

The radical difference between resolving tragic choices and improving both fairness and efficiency was obscured during the 1990s by the peculiar rhetoric of managed care. Rooting out 'waste, fraud, and abuse' was a catchphrase politicians routinely deployed to sidestep tough questions about rationing, but few recognized at the time that mainstream medicine was no paragon of scientific precision or financial self-restraint. As a result, although integrated healthcare delivery and informed consumerism played a part in building enthusiasm for Health Maintenance Organizations (HMOs) among health policy experts, many of the politicians who embraced 'managed competition' expected neither management nor competition. For them, HMOs possessed two advantages over a European-style system of national health insurance. First, money flowing through them would not be reflected on the government's books as raising taxes or increasing public spending. Second, the private suppression of demand by HMOs might be more effective than anything that the national political process could accomplish. Neither of these attributes had much to do with efficiency or consumer choice, and ultimately led to a public backlash against managed care as profit-motivated rationing, which seemed even worse than rationing as a matter of national necessity. ${ }^{20}$

19 IHI Triple Aim Initiative, Inst. for Healthcare Improvement (2015), http:// www.ihi.org/Engage/Initiatives/TripleAim/pages/default.aspx (last visited Sept. 8, 2016).

${ }^{20}$ Cf. Elizabeth McCaughey, 'No Exit', New Republic (Feb. 7, 1994), https:// 
Today, aggregate annual waste in the US healthcare system probably approaches USD 1500000000000 - an almost unimaginable sum. In a 2012 report aptly titled Best Care at Lower Cost, the National Academy of Medicine (which at the time was called the Institute of Medicine) attributed over USD 750 billion each year to waste. ${ }^{21}$ Of this amount, an estimated USD 210 billion reflects unnecessary services, including overuse not justified by scientific evidence, discretionary use beyond established standards, and the unnecessary choice of higher-cost services. The report identified another USD 130 billion in inefficiently delivered services, including medical errors, preventable complications, fragmented care, unnecessary use of higher-cost providers, and operational inefficiency at care delivery sites. Excess administrative costs accounted for USD 190 billion, missed prevention opportunities for USD 55 billion, and fraud for USD 75 billion. The final category, amounting to USD 105 billion in excess annual expenditure, is 'Prices That Are Too High' - meaning that they clearly exceed competitive benchmarks.

From this perspective, the priority task for American health policy is not to devise or broker a definitive national consensus regarding the allocation of scarce public resources, but rather to facilitate incremental, decentralized improvement, largely in the private sector. Moreover, these beneficial activities would occupy the same two domains that the ACA targeted in addition to health insurance: improving the quality and efficiency of medical care, and improving underlying health largely through non-medical interventions.

\section{KNOWN GOALS, ACCEPTED METHODS, LITTLE PROGRESS}

The Triple Aim was not based on a sudden flash of insight. Beginning in the 1970s, researchers from many disciplines examined the U.S. healthcare system and were disconcerted by what they found. Wennberg and colleagues documented large differences in patterns of care from place to place in the U.S. that neither need nor outcomes could justify. ${ }^{22}$ These 'small-area variation' studies became the basis for the Dartmouth Atlas of

newrepublic.com/article/69935/no-exit, last accessed 18 January 2019 (equating rationing under the Clinton reform with private managed care).

21 Inst. of Med., 'Best Care at Lower Cost: the Path to Continuously Learning Health Care in America' (2012) (discussing improved efficiency in healthcare).

22 John E. Wennberg, The Dartmouth Atlas of Health Care in The United States (1996) 2. 
Healthcare in the United States, which quantifies and attempts to explain such inconsistencies. ${ }^{23}$

Donabedian and others attempted to define quality as more than physician custom, developing a structure-process-outcome framework and associated metrics for both technical and interpersonal quality. ${ }^{24}$ Chassin and Galvin divided quality failings into categories of overuse, underuse, and misuse and attempted to quantify each type. ${ }^{25}$ Berwick and Leape, among others, identified system failures in hospitals that led to frequent lapses in patient safety and, in many instances, caused serious harm. ${ }^{26}$ Bioethicists successfully challenged physician paternalism only to discover that patient autonomy, though accepted as a general ethical obligation, was seldom implemented in practice to honour patients' goals and treatment preferences. ${ }^{27}$ Public health researchers cast light on 'epidemic' increases in chronic diseases, identified and quantified the social determinants of health, documented shameful disparities in medical care based on race and other status characteristics, and revealed America's national neglect of non-medical social services. ${ }^{28}$

The National Academy of Medicine's 2012 report on excessive expenditures in U.S. healthcare, discussed above, followed two other book-length evaluations from the same organization. To Err Is Human, published in 1999, assembled over a decade of work on patient safety and revealed medical errors to be, in raw numerical terms, the seventh leading cause

23 Understanding the Efficiency and Effectiveness of the Health Care System, Dartmouth Atlas Health Care (2015), http://www.dartmouthatlas.org (last visited Apr. 17, 2017).

24 Avedis Donabedian, 'Evaluating the Quality of Medical Care', 44 Milbank Memorial Fund Quarterly 166, 167-70 (1966).

25 Mark R. Chassin, Robert W. Galvin, and the National Roundtable on Health Care Quality, 'The Urgent Need to Improve Health Care Quality', 280 JAMA 1000 (1998).

26 Lucian L. Leape and Donald M. Berwick, 'Five Years After To Err Is Human: What Have We Learned?' 293 JAMA 2384 (2005); Paul Weiler, Howard Hiatt, Joseph Newhouse, Walter Johnson, Troyen Brennan and Lucian Leape. A Measure of Malpractice: Medical Injury, Malpractice Litigation, and Patient Compensation (Cambridge, MA: Harvard University Press, 1993).

27 Carl E. Schneider, The Practice of Autonomy: Patients, Doctors, and Medical Decisions (New York: Oxford University Press, 1998); see generally Tom L. Beauchamp and James F. Childress, Principles of Biomedical Ethics (New York: Oxford University Press, $6^{\text {th }}$ ed., 2009) 57-112.

28 See Rebouche and Burris, supra note 8; David Barton Smith, Health Care Divided: Race and Healing a Nation (Ann Arbor: University of Michigan Press, 1999); Dayna B. Matthew, Just Medicine: A Cure for Racial Inequality in American Health Care (New York: NYU Press, 2015). 
of death in the U.S. ${ }^{29}$ Less than two years later, the Academy released Crossing the Quality Chasm. ${ }^{30}$ That report consolidated a generation of policy work into six characteristics that a well-performing healthcare system should possess. In the Academy's view, healthcare should be safe, effective, patient-centred, timely, efficient, and equitable. ${ }^{31}$

The National Academy of Medicine speaks for the uppermost reaches of academic medicine, including physicians and scientists who practise, teach, and perform research at the most prestigious universities in the U.S. The six characteristics in the Quality Chasm report reflect a professional consensus that should be unsurprising. What is more surprising is that the research upon which the report was based clearly revealed that the existing healthcare system in the U.S. had not achieved a single one of the six consensus objectives! The principal value of the report therefore lay in its identification of what the U.S. healthcare system should aspire to become.

In the nearly 20 years since the Quality Chasm report appeared, its clinical consensus on system goals has been joined by a managerial consensus on methods for achieving them. Although many organizations and individuals have put forth recommendations, a logical, practical, and entirely representative set of action steps was articulated around 2010 by Porter and colleagues at Harvard Business School. ${ }^{32}$ Their formulation contains the following steps: (1) organize into Integrated Practice Units; (2) measure outcomes and costs for every patient; (3) move to bundled payments for care cycles; (4) integrated care delivery across separate facilities; (5) expand excellent services across geographic areas; and (6) build an enabling information technology platform. Many healthcare providers and health insurance plans have attempted to follow this advice.

In general, when one knows where one needs to go, and one knows how to get there, the destination shortly comes into view. In American healthcare, that has yet to happen. Care is not much safer than 20 years ago. It is not much more effective. It is seldom patient-centred and often not timely. It is certainly not efficient or equitable. Why, one needs urgently to ask, are we not there yet?

29 Inst. of Med., 'To Err Is Human: Building A Safer Health System’ 37 (1999).

30 Inst. of Med., 'Crossing The Quality Chasm: A New Health System For The 21 st Century’ 83 (2001).

31 Ibid., at 41-54.

32 Michael E. Porter and Elizabeth O. Teisberg, Redefining Health Care: Creating Value-Based Competition On Results (Harvard Business School, 2006); Michael E. Porter and Thomas H. Lee, 'The Strategy That Will Fix Health Care', 91 Harv. Bus. Rev. 50 (2013). 


\section{THE DEEP LEGAL ARCHITECTURE OF U.S. HEALTHCARE}

Different constituencies offer different answers to the question of why so little progress has been made toward consensus policy goals of efficiency and fairness using accepted managerial strategies. Economists point to incentives and, relatedly, to the information on which those incentives are based. Managers point to culture - both professional and institutional. Clinicians point, accusingly, to businesspeople, who sometimes point back to clinicians. Nearly everyone points to politics. Far less frequently, someone points to patients or the public.

All of these explanations have elements of truth. However, the various constituencies all ignore the principal mechanism used by both them and their opponents to impose and perpetuate constraints on the healthcare system, which is the law. ${ }^{33}$

Put simply, governance of U.S. healthcare is based on an idealized image of an individual physician caring for a single patient in a private transaction. ${ }^{34}$ The physician possesses all the characteristics one most wishes for: wisdom, skill, compassion, and incorruptibility. The patient possesses all the characteristics one most sympathizes with: serious illness, vulnerability, and dependence. Each imagined party looks and sounds, moreover, like a character in a television medical drama. The law fosters and protects this therapeutic relationship by empowering the medical profession to set standards for it, by isolating it from direct corporate or governmental control, and by generously subsidizing its costs.

Governance of the U.S. healthcare system is essentially the same legal and financial environment scaled to the population level. Starting about 100 years ago, state governments have repeatedly conferred legal privileges and protections on the medical profession, often relying for both standards and enforcement on private self-regulatory organizations controlled by physicians. Starting about 50 years ago, the U.S. federal government - largely through the Medicare program - has uncritically financed the system that state law created.

33 For a comprehensive review of health law following the enactment of the ACA, see Oxford Handbook of U.S. Healthcare Law, supra note 8.

34 Scholars have universally acknowledged this 'professional paradigm,' but have typically overestimated threats to its dominance. See, e.g., Rand E. Rosenblatt, 'The Four Ages of Health Law', 14 Health Matrix 155 (2004). 


\section{Physician Privileges}

States license physicians to offer whatever medical care they wish, while closely circumscribing the permitted scope of practice for other health professionals and making unlicensed practice a crime. States grant exclusive prescriptive authority to physicians, and have only recently empowered a few other professions to write prescriptions under limited circumstances. States prohibit or penalize outside influences on prescribing, ordering, and referral practices, and some still ban the employment of physicians by hospitals or general businesses as the 'corporate practice of medicine.' At the same time, the federal government has generously funded physician training in hospital settings, leading to a surfeit of medical specialists, and has put in place payment policies under Medicare that favoured physicians over non-physicians, and specialists over general practitioners.

\section{Physician-Hospital Relations}

States have chartered most hospitals as charitable enterprises, which the provisions of federal law for tax-exempt organizations reinforce, thereby providing financial subsidies as well as shelter from market discipline. ${ }^{35}$ State and federal laws have also normalized an 'open medical staff' model of hospital management, in which independent physicians in private practice form a voluntary, collective body that considers applications for membership and - independent of the hospital's administration - grants or denies physician-applicants formal privileges to admit patients and perform medical procedures. ${ }^{36}$ American hospitals thus began life as free workshops for physicians and as community resources, not as competitive enterprises. To the contrary, several states continue to enforce 'certificate of need' laws that prohibit new hospital construction or significant capital expansion without regulatory approval, with existing facilities entitled to register opposition. Combined with prohibitions on 'corporate practice' and insurance billing procedures, these laws have also partitioned and fragmented the provision of complex clinical services within hospitals. ${ }^{37}$

35 See Jill Horwitz, 'Nonprofit Healthcare Organizations and the Law', in Oxford Handbook of U.S. Healthcare Law, supra note 8, 535.

36 See John D. Blum et al., 'The Hospital-Physician Relationship', in ibid., 512.

37 See, e.g., Cal. Bus. \& Prof. Code $\S \S 2400,2052$ (West 2012) (regulations providing that corporations cannot have professional licenses); Tex. Occ. Code Ann. $\S \S 155.001,155.003,157.001,164.052,165.156$ (West 2012) (regulations on corporation's ability to hire physicians). 


\section{Accountability for Quality}

Medical errors remain the primary responsibility of individual physicians under state malpractice law, even for care that is substantially determined by systems and processes within hospitals. As much as physicians fear and resent malpractice suits, ${ }^{38}$ the 'standard of care' that determines whether they are held liable in court is determined by customary practice, as attested by other physicians serving as expert witnesses. When the medical profession and its political allies fight for 'tort reform,' moreover, their principal goal is to keep liability insurance available and affordable to individual physicians, not to provide efficiently for the prevention and compensation of injury. The medical profession also influences hospital quality through its governance role on the Joint Commission, which sets accreditation standards for healthcare facilities on which government relies to determine their eligibility for Medicare payment. ${ }^{39}$

\section{Health Insurance}

State insurance regulation limits health benefits to established designs that will not deceive consumers, but that echo the legal categories just described. Legally mandated coverage divides physicians' own services from the care that physicians order, including hospitalization (with separate 'professional' and 'facility' fees), diagnostic testing, prescription drugs, and durable medical equipment. For many years, state laws prevented insurers from contracting selectively with hospitals or physicians; most of these 'any-willing-provider' or 'freedom-of-choice' statutes have been repealed. However, the legal backlash against 'managed care' in the 1990s imposed additional constraints on health insurers as prudent purchasers of medical services. ${ }^{40}$ Moreover, most private health insurance is still offered through employers, which receive generous federal tax

38 For an explanation of physicians' reaction to medical liability, see William M. Sage, 'Reputation, Malpractice Liability, and Medical Error', in Virginia A. Sharpe (ed.) Accountability: Patient Safety and Policy Reform (Washington, DC: Georgetown University Press 2004) 159-83.

39 See Medical Staff (CAMH/Hospitals), The Joint Comm'n (Mar. 10, 2011). For information about the Joint Commission, see https://www.jointcommission. org/about_us/about_the_joint_commission_main.aspx, last accessed 18 January 2019. See generally James S. Roberts et al., 'A History of the Joint Commission on Accreditation of Hospitals', 258 JAMA 936 (1987).

40 Robert J. Blendon et al., 'Understanding the Managed Care Backlash', 17 Health Aff. 80, 94 (1998) (explaining the causes and manifestations of the public backlash against managed care). 
subsidies and tend not to experiment with innovative forms of coverage for fear of alienating their workers.

\section{Medicare}

In order to secure physician support for what the American Medical Association had long derided as 'socialized medicine,' the original Medicare legislation in 1965 pledged that the federal government would not interfere with medical practice, created distinct financing and payment mechanisms for hospitals and for physicians, and promised payment of physicians' 'customary and prevailing' fees. ${ }^{41}$ The Medicare programme has been substantially altered over time but has paid a steep price for its original design, including the need to institute increasingly strict fraud control measures to reduce false claims, payments to induce referrals, and referrals for services in which physicians have a financial interest. ${ }^{42}$

\section{LEGALLY CONSTRAINED COMPETITION}

This legal environment, and the underlying professional culture upon which it is based, dramatically alter the processes and outcomes of competition in U.S. healthcare. Moreover, both American competition (antitrust) law and the laws of consumer protection assume the desirability of the patterns into which health law channels medical markets, rather than challenging those dynamics. As a result, there are few opportunities to dramatically improve how healthcare markets operate without changing underlying health law.

These are the principal ways in which healthcare regulation distorts competition:

- Fragmented production: co-producers of complex services, notably physicians and hospitals, are usually paid separately and restricted in their corporate structures and industrial relations with each other or third parties.

41 Joseph A. Califano, America's Health Care Revolution: Who Lives, Who Dies, Who Pays? (Random House, 1986) 52; see also William M. Sage, 'Fraud and Abuse Law', 281 JAMA 1179 (1999).

${ }_{42}$ See Joan K. Krause, 'Integration, Fragmentation, and Human Nature: The Role of the Fraud and Abuse Laws in a Changing Healthcare System', in Oxford Handbook of U.S. Healthcare Law, supra note 8, 852. 
- Disaggregated (unassembled) products: most healthcare transactions involve professional process steps to which a billing code has been attached, and isolated physical inputs to those professional process steps. Consumers have few opportunities to buy packaged services that meet their healthcare needs, much less services that are warranted in terms of safety and performance. ${ }^{43}$

- Minimal price competition: widespread health insurance, lack of price transparency, and decision-making by physicians who tend to disregard cost are factors that channel competition into non-price dimensions. ${ }^{44}$

- Low productive efficiency: clinical enterprises tend to understand their revenue streams, many of which are subsidized or determined by politics, far better than their cost structures. As a result, the prices that are paid seldom reflect the minimum cost of production.

- Large insurers and large providers often 'in cahoots': with employers and government providing most of the funding, and with highly localized geographic markets, dominant health plans and dominant hospitals can pursue mutual advantage rather than behaving like true buyers and sellers. ${ }^{45}$

- Many barriers to competitive entry: measures such as professional licensing laws and certificate of need requirements foster exclusionary conduct by incumbents and discourage new entrants, such as non-physician providers of primary care. ${ }^{46}$

- Needlessly small geographic markets: very few healthcare services originate outside the communities where patients live, even where significant shortages exist that could be relieved by innovations such as telemedicine.

- Too many intermediaries who take a cut: faux insurers that process claims but do not actually bear financial risk, physicians who must order or certify nearly all services, and brokerage entities such

43 William M. Sage, 'Assembled Products: The Key to More Effective Competition and Antitrust Oversight in Health Care', 101 Cornell L. Rev. 609 (2016).

44 Gerard F. Anderson et al., 'It's the Prices, Stupid: Why the United States Is So Different from Other Countries', 22 Health Aff. 89 (2003).

45 See, e.g., Scott Allen and Marcella Bombardieri, 'A Handshake that Made Healthcare History', Boston Sunday Globe, Dec. 28, 2008, at A1, A14 (describing insurer-provider cooperation in Massachusetts); W. Penn. Allegheny Health Sys., Inc. v. UPMC, 627 F.3d 85, 91-92 (3d Cir. 2010) (describing insurer-provider cooperation in Pennsylvania).

46 Inst. of Med., The Future of Nursing: Leading Change, Advancing Health (Oct. 5, 2011), http://www.nap.edu/read/12956/chapter/1, last accessed 18 January 2019. 
as pharmacy benefit managers that negotiate multiple financial arrangements regarding single medical inputs all benefit from more rather than less revenue flowing through the system.

- Constrained innovation: the most profitable innovations are those that physicians can order or recommend and that will be separately paid by insurance, channelling research and development into expensive technologies that match current (albeit inefficient) production processes. ${ }^{47}$

- Automation that rarely decreases labour costs: the centrality of physicians and other health professionals to both service delivery and billing results in technology supplementing labour but seldom replacing it, making the U.S. healthcare industry a continuing source of (plausibly unnecessary) jobs and boosting its political influence. ${ }^{48}$

- Little capacity for self-care or individual control: as anyone who has become ill in the evening or on a weekend can attest, the U.S. healthcare system is exquisitely designed to prevent people from taking care of their own basic health needs.

Powerful medical licensing boards, for example, have proved to be extremely persistent in reducing market performance, data and logic notwithstanding. Consider the many benefits that would predictably flow from a more permissive approach to occupational licensing, as enumerated by a Nobel Prize-winning economist. These include more educational opportunity, more accessible care, less expensive care, higher average quality of care (averaging those who can afford fully qualified physicians with those who go without care), more innovative approaches to treatment, more innovative ways of organizing care, healthcare teams, and good ethics without paying more for it. One might imagine the source to be a contemporary economist and commentator, such as Paul Krugman, describing new models of healthcare delivery. Although current

47 James C. Robinson, 'Biomedical Innovation in the Era of Health Care Spending Constraints', 34 Health Aff. 203 (2015) (arguing that the era of 'costunconscious' innovation is finally over).

48 See Katherine Baicker and Amitabh Chandra, The Health Care Jobs Fallacy, 366 New Eng. J. Med. 2433 (2012); see also Employment and Output by Industry, Bureau of Lab. Stat., https:/www.bls.gov/opub/mlr/2016/article/pdf/measuringquarterly-labor-productivity-by-industry.pdf, last accessed 18 January 2019; Lucy Eldridge and Jennifer Price, 'Measuring Quarterly Labor Productivity by Sector', Monthly Lab. Rev. (June 27, 2016), https://www.bls.gov/opub/mlr/2016/article/ measuring-quarterly-lab-productivity-by-industry.htm [https://doi.org/10.21916/ mlr.2016.28], last accessed 18 January 2019 (showing low productivity in health industry). 
reform proposals and policy commentary are strikingly similar, however, this analysis is far from recent. The year was 1962; the economist was Milton Friedman. ${ }^{49}$

Friedman's assertion about ethics merits elaboration. Certain professions, notably medicine and law, exert considerable economic influence in American society, raising a question as to whether market power is a precondition for the desirable attributes of principled professionalism such as charity, beneficence, and forbearance of profit. ${ }^{50}$ Defenders of professional privilege worry that an unfettered market will result in unneeded services, poor quality, the financial exploitation of the middle class, and the exclusion of the poor, Friedman was sceptical more than half a century ago, and the well-documented inefficiency and inequity of present-day healthcare support his view. Even if physicians themselves have generally behaved well, many others that provide inputs to physician-directed care have not, while the system as a whole suffers from insularity, wishful thinking, and the many problems of moral hazard and collective action that arise when large amounts of public money flow through obscure channels from payer to recipient.

Moreover, American physicians vigorously resist a more holistic, less deferential health policy as contrary to the 'free-market' ideology which they routinely yet incorrectly credit for their financial success. Replying 20 years ago to one such physician, Princeton health economist Uwe Reinhardt (who, sadly, passed away in late 2017) was blunt in his criticism:

[Dr.] Lally writes of 'a fierce sense of rugged individualism, independence, and self-reliance that have been and still are the hallmarks of the American ethos.' Where are these rugged individualists? . . Would I find them in the medical profession, whose members rely so heavily on public subsidies for their education and the science they apply, who now seek a federal tax preference for medical savings accounts, who plead with government to punish managed care organizations that are late in paying bills, to impose on managed care organizations any-willing-provider laws, and to regulate managed care organizations with countless other strictures, and who have never balked at using archaic licensure laws to protect their own economic turf? ... As all of these self-styled, rugged individualists enlist their government's coercive power to protect their own fiscal health, they might more gracefully countenance the use of that power and also protect the physical health of poor children and, indeed, of all poor people. ${ }^{51}$

49 Milton Friedman, Capitalism and Freedom (University of Chicago Press, 1962) 149-59.

50 Ronald J. Gilson, 'The Devolution of the Legal Profession: A Demand Side Perspective', 49 MD. L. Rev. 869 (1990).

51 Uwe E. Reinhardt, 'Letter to the Editor, Articulating a Social Ethic for Health Care', 279 JAMA 745 (1998). 


\section{IMPLICATIONS FOR HEALTH SYSTEM GOVERNANCE}

The revised understanding of American health policy presented in this chapter offers guidance for future improvements in healthcare and health, some of which may be applicable internationally. The U.S. wastes well over USD 1000000000000 each year on ineffective, overpriced, poorly delivered, and/or inaccessible medical care. Seen from so far off what economists term the Pareto frontier, the healthcare system's problems and their potential solutions are quite different than had appeared to be the case under prior assumptions of professional optimality challenged by scientific progress. Three lessons seem most important to summarize, all of which derive from the demonstrable inefficiencies and inequities of U.S. healthcare.

First, the various ideological 'brands' associated with national health reform must realign themselves to the task of facilitating decentralized, incremental improvement rather than asserting a national political consensus on setting limits. This is particularly true of 'single-payer' proposals modelled on countries with national health insurance systems. Recent single-payer advocates have proposed expanding the existing Medicare programme to cover a much larger percentage of the U.S. population. If one takes that approach, restructuring how healthcare is paid for and delivered in order to improve its productive efficiency is a more pressing need than imposing price controls or limiting new technologies. Medicare expansion, moreover, would almost certainly occur through growth of the Medicare Advantage programme, where patients enrol in private health plans, rather than traditional Medicare, and where the federal government pays hospitals and physicians directly. This would create additional opportunities to promote efficiency through meaningful competition rather than by politically constraining administrative costs or profits. Similarly, proponents of 'consumer-directed' financing such as Health Savings Accounts would be well advised to focus less on saddling patients with high, uninsured costs for current models of care in order to counter moral hazard, and more on making prices transparent for assembled services (with warranties if possible) that meet clear medical needs. Health plans on the Obamacare insurance exchanges (also called the 'marketplace'), which are based conceptually on 'managed competition' but in practice serve mainly low-income families who are eligible for tax subsidies, should devote more attention to offsetting the adverse effects of the social determinants of health, which in turn would enable value-based care models to serve patients more effectively. For example, medical-legal partnerships could be embedded in clinical settings to assist patients with 
health-harming legal needs involving income, insurance, housing, education, employment, legal status, and family relationships. ${ }^{52}$

Second, in addition to continuing routine enforcement of the antitrust laws, the U.S. Department of Justice and the Federal Trade Commission should pursue longer-term strategies intended to reverse the distortions currently burdening competition that have been described in this chapter. The greatest need is to break down barriers to market entry by individuals and organizations offering lower cost, more convenient models of care. Doing so will often require challenging the self-protective behaviour of incumbents, sometimes acting under colour of state law. A milestone achievement was the United States Supreme Court's 2015 decision in FTC v. North Carolina State Board of Dental Examiners, ${ }^{53}$ in which the Federal Trade Commission successfully challenged a dental licensing board's threats to criminally prosecute non-dentists offering basic teeth whitening services in shopping malls. The Supreme Court held bluntly that state professional licensing boards controlled by members of the licensed profession are subject to federal antitrust oversight and potential liability unless they are actively supervised by actual state government. Because of the North Carolina Dental decision, previously self-protective licensing boards may become less openly hostile to other professionals (or non-professionals) offering similar services, and more accepting of new forms of service provision such as telemedicine. ${ }^{54}$ Another productive area for competition law is ensuring that dominant health plans and hospitals do not collude to divide markets or exclude new competitors.

Third, America's spendthrift healthcare system is particularly problematic because it leads the political process to medicalize problems such as poverty, lack of education, and substandard housing - over-investing in medical care and under-investing in non-medical social services that would be less costly, more effective, and more accessible to disadvantaged populations. ${ }^{55}$ Work by Bradley and others confirms that European and

52 See B. Krishnamurthy, S. Hagins, E. Lawton, M. Sandel, 'What We Know and Need to Know About Medical-Legal Partnerships,' 67 S.C.L. Rev. 377 (20152016) (describing efforts to identify and address health-harming legal needs).

53 N.C. State Bd. of Dental Exam'rs v. FTC, 135 S. Ct. 1101 (2015); see also William M. Sage and David A. Hyman, 'Antitrust as Disruptive Innovation in Health Care: Can Limiting State Action Immunity Help Save a Trillion Dollars?', 48 Loy. U. Chi. L.J. 724 (2017) (discussing the connection between stronger competition oversight of professions and health system improvement).

54 See, e.g., Teladoc, Inc. v. Tex. Med. Bd., 122 F. Supp. 3d 529 (W.D. Tex. 2015) (denying motion to dismiss antitrust suit against state medical board on ground of state action immunity).

55 See, e.g, Megan Sandel and Matthew Desmond, 'Investing in Housing for 
Commonwealth countries balance medical and social investment more successfully than the U.S. ${ }^{56}$ The percentage of GDP devoted to both medical and social spending by the U.S. falls near the median value, but America spends more than two-thirds of that amount on medical care, while nearly all other countries spend more than half on social care (many significantly more). Yet medical spending in the U.S. very closely tracks poverty, strongly suggesting that non-medical investment in relieving poverty would be preferable. ${ }^{57}$ Although the U.S. would need to demonstrate a degree of social solidarity sufficient to make this commitment, ${ }^{58}$ liberating resources that are currently trapped in America's grossly inefficient healthcare system by accreted health law - in essence, 'fracking' healthcare - would greatly increase the likelihood of success. ${ }^{59}$

Health Improves Both Mission and Margin,' 318 JAMA 2291 (2017) (prioritizing housing). See also William M. Sage and Jennifer E. Laurin, 'If You Would Not Criminalize Poverty, Do Not Medicalize It,' 46 J. L. Med. \& Ethics 573 (2018) (offering a cautionary tale about medicalizing social problems).

56 Elizabeth H. Bradley and Lauren A. Taylor, The American Health Care Paradox: Why Spending More is Getting Us Less (Yale University Press, 2015) (discussing U.S. lack of social investment).

57 Richard Cooper, Poverty and the Myths of Health Care Reform (Johns Hopkins University Press, 2016) (using poverty to explain geographic variation); Raj Chetty et al., 'The Association between Income and Life Expectancy in the United States, 2001-14', 315 JAMA 1750 (2016).

58 William M. Sage, 'Why the Affordable Care Act Needs a Better Name: "Americare", 29 Health Aff. 1496 (2010); William M. Sage, Solidarity, in Thomas H. Murray and Mary Crowley (eds), Connecting American Values With American Health Care Reform 10 (Garrison, NY: The Hastings Center, 2009); William M. Sage, 'Brand New Law! The Need to Market Health Care Reform', 159 U. Pa. L. Rev. 2121 (2011).

59 William M. Sage, 'Fracking Health Care: The Need to Safely De-Medicalize America and Recover Trapped Value for Its People,' 11 NYU Journal of Law and Liberty 635 (2017). 